\author{
Олена Миколаївна Холодьон \\ Інститут української мови НАН України \\ Київ \\ ORCID: 0000-0001-7546-6479; e-mail: kholodonolena@gmail.com
}

\title{
Дісслівна лексика і семантика в українських говорах: стан та перспективи дослідження (дескриптивний аспект)
}

\begin{abstract}
Реферат: У статті охарактеризовано стан дослідження діалектної дієслівної лексики в українських говорах у діалектних дескриптивних працях, зокрема виокремлено напрями: зв'язки з літературною мовою, зв'язки 3 іншими діалектами, етимологія, конотація, дієслівна лексика як системно-структурне утворення та семантика дієслів, дієслівна фразеологія, сполучуваність, дієслово в словнику. Хоча сьогодні вивчення діалектної дієслівної лексики пожвавилося, здійснено системне дослідження дієслів східнополіських говірок, проте загалом дієслівну лексику в українських говорах вивчено недостатньо, тому існує потреба в комплексних, системних наукових дослідженнях. Окреслено основні проблеми в подальшому вивчення діалектних дієслів в українських говорах.
\end{abstract}

Ключові слова: українські говори, діалектна дієслівна лексика, дескриптивний аспект.

Abstract: Verb lexicon and semantics in the Ukrainian dialects: the state and prospects of the study (Descriptive Aspect). The verb lexicon has a central place in the part-language hierarchy and a priority in the nomination of actions and processes (I.R. Vykhovanets, K.H. Horodenska). According to M.I. Tolstoi ,the most appropriate material for semantic research is an abstract lexicon, in particular thematic groups of words arranged in accordance with different parts of language. The article describes the status quo of studies on the dialectal verb lexicon in Ukrainian dialects in descriptive works, in particular the connections with the literary language, the connections with other dialects, the etymology, connotations, the verb lexicon as a systematic and structural unit and verb semantics, verb phraseology, connectivity, verb in the dictionary. Despite the recent revival of studies in the dialectal verb lexiconand a systematic study of East Polissian verbs, in general the verb lexicon does not embrace enough Ukrainian dialects so there is a need for complex, systematic scientific research. The article outlines the main problems in continued studies of dialectal verbs in Ukrainian dialects.

Keywords: Ukrainian dialects, dialectal verb lexicon, descriptive aspect.

Пріоритетною у сучасній українській діалектології є проблема системного дослідження діалектної лексики українських говорів, яку науковці вивчали в межах тематичних (ТГЛ) і лексико-семантичних груп (ЛСГ) (Й.О. Дзендзелівський, М.В. Никончук, Г.Л. Аркушин, П.Ю. Гриценко, І.В. Сабадош, В.М. Куриленко, Н.В. Хобзей, В.В. Лєснова, Г.І. Гримашевич, М.В. Поістогова, Н.П. Дейниченко, Л.І. Дорошенко, Є.Д. Турчин, О.А. Жвава, Т.П. Кукса, В.П. Різник та ін.). Дієслівну лексику здебільшого аналізували принагідно, часто поряд з іменними частинами мови. Дієслівна лексика посідає центральне місце в частиномовній ієрархії, їй 
властива пріоритетність в номінації дій та процесів (Вихованець 2004, 217-218). Відомий дослідник Полісся M.I. Толстой відзначав, що найпридатнішим матеріалом для семантичних досліджень є абстрактна лексика, зокрема тематичні групи слів за різними частинами мови (Толстой 1997, 43). Діалектні дієслова - важливий засіб пізнання зовнішнього і внутрішнього світу діалектоносіїв, особливостей їхньої життєдіяльності, інтересів, ставлення до світу та людей.

У вітчизняній українській діалектології науковці описували стан дослідження назв одягу та взуття (Г.І. Гримашевич), ботанічної лексики (М.В. Поістогова, I.В. Гороф'янюк, Р.С. Омельковець), пастуших назв (Т.О. Ястремська), лексики родинних обрядів (О.А. Жвава), ентомологічної лексики (Л.М. Шуст), назв їжі та кухонного начиння (В.П. Різник), орнітолексики (Я.О. Литвиненко) та ін., проте відсутні розвідки, які відтворили б стан вивчення діалектної дієслівної лексики i семантики в українських говорах, що зумовлює актуальність нашого дослідження.

Мета дослідження - проаналізувати стан вивчення діалектної дієслівної лексики і семантики в дескриптивних працях та звернути увагу на основні проблеми в їх подальшому дослідженні.

\section{Дескриптивний аспект}

Аналіз наукової літератури засвідчує, що діалектне дієслово досліджували на різних мовних рівнях, зокрема вивчали особливості акцентуації, словотвору, словозміни, синтаксису дієслова, порушували питання динаміки й варіантності на цих рівнях (І.Г. Верхратський, Ю.С. Виноградський, Ф.Т. Жилко, Г.П. Їжакевич, П.С. Лисенко, В.С. Ващенко, Л.І. Дорошенко, І.Д. Пагіря, А.І. Філіппова, Н.Й. Марчук, В.В. Німчук, Т.В. Назарова, Т.М. Возний, М.Ф. Кобилянська, М.Б. Яким, К.Д. Глуховцева, Г.І. Мартинова, Г.С. Кобиринка, А.О. Колесников, Д.А. Мареєв та ін.).

У «Програмі для збирання матеріалів до Лексичного атласу української мови» Й.О. Дзендзелівського в розділі «Дієслова, прислівники та інша загальна лексика» дієсловам присвячено 52 пит. (Дзендзелівський 1987, 274-295), в інших розділах, напр., «Будівництво» - 7 пит., «Рибальство» - 4 пит. та ін. (Дзендзелівський 1987, 56-60, 76-98).

У діалектних дескриптивних студіях науковці досліджували дієслівну лексику в різних напрямах.

Зв'язки з літературною мовою

Процес взаємодії української літературної мови та діалектів на матеріалі дієслівної лексики вивчав Т.М. Возний (1978), який простежив спільні та відмінні риси у порівнянні з літературною мовою, виявив особливо тісні взаємовпливи серед відвигукових бойківських дієслів на -oma/mu/, -omi/mu/ та виділив 4 типи таких дієслів. Особливості дієслівних діалектних варіантів у порівнянні з літературно-нормативними розглянула М.Д. Карп’юк, залучивши до аналізу й інші мови (Карп’юк 1978). 


\section{Зв'язки з іншими діалектами}

Пошуком паралелей для дієслів з префіксом ви- (напр., вигиба́ти, виду́рюваmи, вибивати, висипатися) в говірках північного та південно-західного наріччя української мови займалася Н.В. Хобзей (2010б), яка зазначила, що для грунтовних достовірних порівнянь діалектних явищ у різних говірках важлива не тільки ix лексикографічна репрезентація, а й максимальне дослідження записів живого мовлення як системи.

Східнополіські діалектні дієслова мовлення (напр., ба'лакат', гама'н'іт', гу'тарит' 'розмовляти'; беле'мешит', пл'е' вузкат' 'говорити дурниці, нісенітниці'; 'байат' 1) 'правдоподібно, гарно розповідати нісенітниці, брехню’; 2) 'колихати дитину'; зв 'е' гат' 'дорікати, прискіпуватися' та ін.) у контексті української, російської і білоруської мов проаналізовано О.М. Холодьон (2016).

\section{Етимологія}

У лексико-етимологічному й ареальному аспектах Г.І. Ковач розглянула дієслівні характеристики об’єктів полювання на позначення лексико-семантичної мікрогрупи 'огризатися, скалити зуби (про звіра)' в українських говірках Закарпаття (Ковач 2011) та виявила, що репертуар досліджуваних дієслів засвідчує переважно звуконаслідувальну базу їх творення (напр., гыр'чати, к'лацати, к'ланцุати, к'льнцати, к'лацкати, к'лоцати, фыр'чати, х'лапкати, ц'ванкати, 'чапкати, ч'мохати та ін.), частина яких має давнє праслов'янське коріння (c'кaлити, шкреб'ти). Дієслівні словосполуки ('піну то'чити, ри'піти у 'зуби, 'p'iза$m u$ y 'зубы) на позначення досліджуваної мігрогрупи виділено окремо.

\section{Конотація}

На конотацію діалектної лексики звернув увагу В.А. Чабаненко, аналізуючи лексику степових говірок Запорізької області (Чабаненко 1977). Автор зазначив, що серед досліджуваної лексики переважну більшість емоційно-експресивних слів становлять іменники та дієслова.

Дієслова, які стали основою семантичної експресії діалектного тексту, охарактеризувала К.Д. Глуховцева (2008). Авторка проаналізувала дієслова 3 етнокультурним значенням у східнослобожанських говірках, дієслова, утворення яких пов’язане з господарською діяльністю носіїв мови, звичаєвістю тощо, які за своїм значенням наближаються до сленгізмів, називають дії, приписувані тваринам, птахам, позначають етапи розвитку рослин. К.Д. Глуховцева зробила висновок, що завдяки багатозначності дієслова в усному мовленні «обростають» позитивними і негативними конотаціями (напр., тьохкати 'лагідно говорити' (позитивна конотація), ‘улесливо говорити' (негативна конотація); наливатися 'вливаючись, натікаючи, наповнювати що-небудь', 'наповнюватися рідиною', 'сповнюватися якимись почуттями, властивостями і т.ін.', 'наповнюватися соком (про плоди, зерно і т.ін.)', 'спіти', ‘напиватися до п’яну', 'пити або їсти багато чого-небудь рідкого’ (здебільшого позитивна конотація); замуздикати 'замучити', замуздиканий ‘замучений важкою роботою’ (негативна конотація) та ін.).

Конотативні значення дієслів із семантикою руху в говірках Закарпаття розглянула О.В. Юсікова (2010) та зазначила, що ядром семантичного поля є назви iз значенням 'іти', 'бігти' та похідні. У статті виділено релевантні щодо конотативної диференціації семи: 'темп руху' (напр., 'пазитис'а, пело'вати (пилу'вати) 
'швидко йти, бігти'; при'лапкати, прича'лапкати, при'm'опати 'приплентатись'), 'супровідна поведінка людини під час руху' (напр., па'лайдати 'іти, високо піднімаючи ноги'; пере'кыцатис'а 'іти, нахиляючись то в один, то у другий бік'; пришко'пырдати, прил'о'говдати, пришкул'гицати, приш'кунчати 'іти, накульгуючи'), 'душевний стан суб'єкта руху’ (напр., пе'канити (пе'конити) 'нахабно заходити'; приш'кынтати 'прийти, будучи змученим, хворим'), 'місце руху' (напр., пла' йачити 'іти плаєм'; переса'лашитис' $a$ 'переходити з отарою ночувати на інше місце'; перело' пьндати 'перейти через воду'), 'час руху' (напр., пора'ниmи 'прийти раніше'; при'n'iти (при'пути) 'піти на довгий час'), 'ставлення мовця до руху' (напр., прива'литис'а 'прийти, коли не чекають').

Семантику емоційно забарвлених дієслів, які виражають негативну оцінку, в українських говорах досліджувала В.В. Лєснова (2011). Методом суцільної вибірки 3 діалектних словників авторка обрала дієслова, супроводжені ремаркою зневажливе (355 лексем 311 словників), та проаналізувала дієслова таких ЛСГ: 'Говорити, розмовляти' (56 лексем: напр., балабенити, дзяльохати, дзярамати 'беззмістовне мовлення'; бевкати, льопотіти 'недоречне мовлення'; шєлєпати 'говорити невиразно', 'базікати' та 'шелестіти'), 'Готувати або вживати їжу, напої' (50 лексем: напр., вартачіти, напарджьолювати, тофланити 'готувати їжу недбало, нашвидкуруч тощо'; зафляцкати 'приготувати розчину для хліба, пирога тощо'; вітаскувати, натрощитис'и, накуватися 'їсти багато, переїдати'; валакувати, мамлєти, нямкати 'їсти повільно'; спакувати, тевкати, халасувати 'їсти (з'істи) швидко'), 'Ходити, пересуватися в просторі' (45 лексем: напр., тифурити, турлюжитися, шмірувати 'іти'; бейкатися, бомбатиси, клендати, ландати, шнякатис 'ходити без діла'; валанцатиси, к'игатис'и, к'игнутис'и, телембатиси, тирлибати 'іти, ходити повільно'); виокремлено також групу зневажливих дієслів, які характеризують поведінку людини (76 лексем: напр., варкатиси, гіикатиси, копирчитиси 'сваритися'; коляриться, скапилюшитиси, сконфузитиси 'сердитися, розсердитися'; вихехелюватися, джегоритиси, перчітиси, пирожитися 'чванитися, гонорувати').

Дієслівна лексика як системно-структурне утворення та семантика дієслів

Дослідники часто принагідно, поряд 3 іншими ЛСГ аналізували лексику на позначення дій, пов'язаних з оброблянням землі, вирощуванням сільськогосподарських культур, збиранням і збереженням урожаю в південнобесарабських говірках межиріччя Дністра і Дунаю (Гриценко 1984, 60-72), в слобожанських говірках (Сердега 2012, 101-109), в говорах Закарпаття (Дзендзелівський 1960); дій і процесів, пов'язаних із ткацтвом у східнослобожанських говірках (Ніколаєнко 2005, 24-40); дій і процесів, пов’язаних з недугами та зціленням від них (Романина 2015, 157) та ін. Дієслівну лексику наддністрянського говору 3.М. Бичко поділив за об'єктами реальної дійсності:

1) жива матерія (люди, тварини, рослини);

2) нежива матерія (натурфакти [явища природи], артефакти [одяг, взуття, продукти харчування, напої, процеси обробки, переробки і господарювання]) та подав приклади дієслівної синонімії, омонімії та полісемії (Бичко 2000, 209-220; 2001).

Досліджуючи систему звуконаслідувальної лексики українських говорів Карпат, Ю.В. Юсип-Якимович зазначила, що кожна 35 описаних ЛСГ ономатопів 
має в говорах свій словотвірний потенціал, своє коло похідних; структура словотвірних гнізд залежить від потенційних можливостей вихідних слів, що належать до якогось із виділених семантичних розрядів. Авторка звертає увагу, що основне ядро дериватів від звуконаслідувань становлять відономатопоетичні дієслівні утворення, серед яких активно функціонує сім словотвірних моделей: $3+-a-$ (ти) (напр., дзурк-а-ти, чмах-а-ти, иввіг-а-ти, шух-а-ти, бевх-а-ти та ін.), 3+-ка(ти) (напр., лус-ка-ти, дзилин'-ка-ти, калат'-ка-ти, дуп-ка-ти, вав-ка-ти та ін.), 3+-i-(ти) (напр., скум-i-ти, брым-і-ти, джур-i-mи, хрум-i-mи, сап-i-ти та ін.), 3+-ча-(ти) (напр., трун-ча-ти, пул'-ча-ти, крав-ча-ти, бжін'-ча-ти, бул'-ча-ти та ін.), 3+-оті-(ти) (напр., чаламп-оті-ти, чвак-оті-ти, гр'ак-оті-ти, гіг-оті-ти, чех-оті-ти та ін.), 3+-ота-(ти) (напр., мекек-ота-ти, кл'ук-ота-ти, стр' ӱк-отати, имок-ота-ти, йегог-ота-ти та ін.), 3+-ну-(ти) (напр., цилік-ну-ти, чах-ну-ти, кріц-ну-ти, фл'ос-ну-ти, чубовк-ну-ти та ін.) і їх варіанти. Найпродуктивнішою $\epsilon$ модель 3+-ка-(ти), за якою утворено 464 дієслівні деривати, потім 3+-ну-(ти) 184 дієслова, 3+-a-(ти) - 170 і т.д. (Юсип-Якимович 2007, 98-171).

Проаналізовано дієслова лексико-семантичного поля 'Аграрне виробництво (рослинництво)' в гуцульських говірках, зокрема виділено критерії ідентифікації дієслів досліджуваного лексико-семантичного поля та розглянуто дієслова, які відрізняються від літературних відповідників фонетично і структурно; виокремлено 8 ЛСГ, які позначають різні етапи аграрного виробництва (рослинництво) та виявлено, що найбільше номінують процеси тієї галузі рослинництва, яка найбільш поширена на Гуцульщині - заготівля сіна для худоби (Познанський 2012, 2013a, 2013б).

Структурну та семантичну організацію назв на позначення дій та процесів, пов'язаних з аграрним виробництвом, розглянув (Бігусяк 2015) та виділив 9 ЛСГ дієслів на основі виокремлення хронологічно впорядкованих етапів аграрного виробництва, зокрема рослинництва:

1) дієслова на позначення процесів обробітку грунту,

2) дієслова на позначення процесів обробітку насіння,

3) дієслова на позначення процесів садіння чи сіяння насіння,

4) дієслова на позначення процесів догляду за рослинами під час їхнього росту та дозрівання,

5) дієслова на позначення процесів збирання врожаю,

6) дієслова на позначення процесів підготовки реманенту,

7) дієслова на позначення процесів завдання шкоди аграрному господарству,

8) дієслова на позначення процесів, які безпосередньо не здійснюються людиною, в тому числі пов'язаних із ростом та дозріванням рослин та зі знищенням, загибеллю рослин,

9) дієслова загальної аграрної семантики.

Також окреслено динамічні процеси в семантиці назв у говорах Івано-Франківщини та встановив роль загальнонародної лексики у формуванні галузевої термінології сільського господарства. Автор зробив висновок, що більшість назв окремих ЛСГ не репрезентовані спеціальними лексемами, на їх позначення використовують у говірках літературні номінації, як правило, фонетично адаптовані до народної вимови, до яких дослідник відніс дієслова на позначення процесів 
обробітку грунту, насіння, процесів сіяння та дієслова загальної аграрної семантики.

Номінацію обрядодій передпологового і власне пологового етапів родильного обряду у східноподільських говірках розглянула (Тищенко 2009), а також указала на принципи і способи номінації обрядодій та розкрила їх семантику, напр., початок власне родильних обрядодій, пов'язаних з приходом баби-повитухи, яку запрошували до породіллі, коли у тієї вже почалися перейми, номінують назвами зл'аг'ти, зл'аг'ти на 'роди, зл'аг'ти ро'дити, откри'вати зам'ки. Для номінації процесу народження вживають лексеми ро'дити, наро'дити, поро'дити, 'виродиmи, розро'дитис'а. Обрядодія 'відділення дитини від матері' пов'язує дві частини: обрядодія 'перев'язування пуповини' - зауйа'зати пуп, зауйа'зати 'пупчик, уйа'зати пуп, заўйа'зати пупо'вину; обрядодія 'розрізання пуповини' - одри'вати 'пупа, в·ідр'i'зати пуп, одр 'i'зати пупо'вину, в·ідр'i'зати пупеи', пе ре р'ізувати пупо'вину, одтм'ч 'іпувати пупо'вину, ру'бати пуп та ін. Дослідниця зробила висновок, що основним принципом мотивації назв $\epsilon$ дія, яку виконують учасники обряду.

На матеріалі дієслівної лексики східнополіських говірок проаналізовано евфемізми як чинник лексичного варіювання (Холодьон 2016). Авторка зазначила, що значення 'померти' реалізоване дієсловами, утвореними від кореня -мер- (-м'ер-, -м'ір-, -м'ор-): y'мерти, y'м'ерт', y'м'ерт 'i, по'мерти, па'мерти, етимологія яких, на думку дослідників, дає підстави знаходити прагнення до евфемізації. 3'ясовано відмінні мотиви евфемістичних номінацій та виявлено, що більша частина лексики переважно прозора за своєю внутрішньою формою, мотивація якої сягає язичницьких уявлень про смерть, напр., мотив «переходу» та «відходу» до іншого світу відображають одиничні дієслова й конструкції з дієсловом іти + обставина місця: пайш'ла, ади'шоў, у 'в 'ічнос'и̧' одиш'ла, паш'ла на той св'ет; міфологічний мотив, що пов'язаний зі світовим деревом, яке у слов'ян переважно асоцієються з дубом,

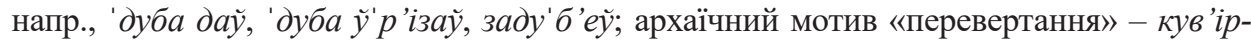
к'нуусс' 'а, у'же пака' тиўс' $а$, пере' кинуўс' $а$; мотив ритуального обрядження покійника - уб' раўс'a; мотив закопування покійника в землю - y'же паха' вали, у'же зака' пали, за' сипали зем'л'о̆ та ін. Для з'ясування затемненої мотивації лексем, напр., ака'чурилас', 'вишкуриусс'а, з' гирдиусс'а, чикул' дихнуўс'а, залучено дані лексикографічних, лінгвогеографічних та дескриптивних джерел. Також наведено дисфемістичні номінації на позначення цього значення, напр., здох, па'дохла, пра' паў, ад'л'апаусс'а, ска' n'im 'іўс'а, ад'л'аскалас' та ін.

Досліджено невербальні засоби вираження семантики дієслів Східного Полісся, зокрема описано види і функції жестів, охарактеризовано особливості їх функціонування у діалектній комунікації (Холодьон 2019).

Семантику дієслів буковинських говірок вивчала В.А. Прокопенко (1961), яка розглянула загальновживану дієслівну лексику, залишивши поза увагою специфічну діалектну дієслівну лексику сільськогосподарського виробництва та різних ремесел. Авторка зауважила, що значення дієслів переважно збігаються з літературними відповідниками, але деякі дієслова відрізняються від літературного стандарту своєю семантикою або мають додаткові значення. Серед прикладів навела такі дієслова, як класти, сидіти, іти, гуляти, знати, рубати тощо. Семантику 
дієслова класти в говірці села Богдан Рахівського району Закарпатської області проаналізувала О.В. Юсікова та виділила у семантичній структурі цього дієслова значення 'садити', 'розписатися', ‘збудувати', 'називати', 'встановити', 'готувати (про страви)’ та ін. (Юсікова 2013).

Дієслова з префіксом ви-, які в говірках південно-західного наріччя познача-

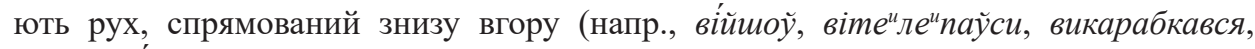
віньіс, ві́бисажиў, в ’к’ігнути та ін.), вивчала Н.В. Хобзей (2011в). Дослідження грунтується на системно записах живого мовлення, архівних матеріалах до другого тому «Атласу української мови», опублікованих діалектних текстах та лексикографічних працях. Дослідниця зазначила, що відповіді на запитання «звідки?» та «куди?» майже в усіх дієсловах руху та переміщення є обов'язковими, вони становлять комунікативні валентності дієслова. Також Н.В. Хобзей проаналізувала значення видової пари вискакувати/вискочити в говірках південно-західного наріччя української мови, зокрема й у складі ідіом та паремій та зробила висновок, що у процесі семантичного розвитку важливими $є$ початкова та кінцева точки („куди?” і „звідки?”), а також ознака раптовості, миттєвості (стрімкості) руху (Хобзей 201б).

На матеріалі діалектних текстів українських говірок Воронезької області семантику дієслів фізичної дії в аграрному дискурсі вивчала Т.В. Міроненко (2014) та простежила збереження семантики власне українських дієслів сіяти, косити, орати, боронувати й ін., відтінки їх значень у різному контекстуальному оточенні та вплив російських говірок на їх семантику.

Здійснено системне вивчення діалектних дієслів східнополіських говірок, зокрема досліджено дієслова руху, мовлення, розділення, приготування їжі, фізіологічної дії та завдавання удару (Холодьон 2017). Визначено склад та семантику номінативних одиниць, що репрезентують окреслене коло понять, установлено закономірності формування структури проаналізованих ЛСГ дієслів та виявлено семантичні відношення і явища в межах цих груп, зокрема:

1) синонімію (сема 'говорити швидко': ма'лот', мала'тит', тере'бенит', беле'бенит', пек'ти, с'ік'ти, ба'лакат' 'p'асно, пе'че од'но за дним, 'цокат' йак з 'пушки, га'ворит' йак хвас'том 'меле, с'іч'е йак с'іч'карка, тарах'тит' йак y 'm'ерн'іиу, ад'но с'лово начи'найу д'руге кан'чайу, ў ми'нутину дак мо сто слоў випус'кайе, пайш'ла ц пайш'ла ц̆ пайшла та ін.),

2) антонімію (сема 'їсти повільно’: жу'ват', жо'ват', жват', п'л'амкат', ч'в 'ан 'кат', чв'йалкат', 'шаўкат', 'йісти 'нехат'а, два ча'са с'а'д'im', спит' над 'мискай, п'л'амкайе йак нежи'ве, жу'йеш йак у мед пли'веш та ін. / сема 'їсти швидко': 'жерти, ру'бат', лу'пит', ма'лотит', гла'тат', ли'гат', упл'і'тат', х'ламом брат', по'йіло на 'захватки, н'е же'ваўши пакай'тат', 'вихватай-'вихватай $і$ га' тоў та ін.),

3) квазіантонімію (сема 'споживати їжу': 'йісти, 'кушат', упатреб'л'ат', ш'л'амд 'ат', мул 'гу'ват' / сема 'не поїсти, колупаючи, бовтаючи їжу': 'боуттащ:a, кала'мутит', калу'пат', кави'р'аu::а, кавир'сат', 'риц:а, кови'р'айес': а 'наче со'рока уу 'к'іс'и'і $і$ та ін.),

4) гіперо-гіпонімію (за ДО 'мати вади мовлення' щодо семеми 'говорити' видовими є семи 'мати нечітку чи спотворену вимову звуків' (шеле'л'авит', шеге ' p'am', 
кар'тавит', не 'каже, не до'казуйе, йа'зик за' путуйец::а, перекриў'л'айеи:а ўсе та ін.), 'не вимовляти «р»' (кар'тавит', кер'тавит', ииг'і' р'ат', гар'кавит', хор'кавит', гар'кат' та ін.), 'вимовляти «ш» на місці іншого звука' (шепе'л'ат', шепе'л'авит', 'шикат', 'шекат'), 'вимовляти «с» на місці іншого звука' ('с'оўкат', 'c'укат', ca'nam'), 'вимовляти «л» на місці іншого звука' ('л'екат'), 'не вимовляти «к»' (к’ip'dam'), 'заїкатися' (зайі' кац('): a),

5) семантичну локалізованість (сема 'заготовляти продукти': зак'ручуват', зака'тат', кансер'в 'іруват', к'лас'm' $\check{y}$ 'банк'i, зараб'л'ат' у 'банки та ін.; сема 'бити ногою (носком)': фут'болит', са'л'ат', 'нос'и'ікам у'дарит', у'дарит' 'виспеткам та ін.; сема 'готувати м'який сир у печі, духовці': атвара'жит' та ін.),

6) семантичну фузію (лексеми 'бахнут', m'p'icнуm', 'л'anam', га' с'іm'),

7) семантичний паралелізм (лексеми 'л'ізти і n'лават', ш'л'оnam'i 'm'onam'),

8) енантіосемію (накаш'личит', навар'ганит', нал'а'пошила, наман'тул'іт', накоў'басит' та ін. на позначення сем 'приготувати щось швидко та недбало, абияк' та 'приготувати щось швидко, але якісно').

Також простежено моделі семантичного варіювання досліджуваних дієслів (iти/ходити, балакати/гомоніти, різати, пекти, їсти, бити), з'ясовано чинники їх варіювання та окреслено тенденції просторової поведінки сем.

Дієслівна фразеологія

В окремих розвідках висвітлено особливості функціонування фразеологізмів із значенням акту мовлення в південно-західних українських говорах ареалу Карпат (Лавер 1977); ономасіологічний аспект фразеологізмів зі значенням 'бити, карати' в українських народних говорах (Івченко 1999).

Н.В. Хобзей розглянула реалізацію дієслів руху з префіксом ви- в колядках та щедрівках (Хобзей 2010в), багатозначні дієслова вилітати/вилетіти, виводити/ вивести, виходити/вийти у складі ідіом та паремій (Хобзей 2010a; 2011a; 2012) на діалектному матеріалі говорів південно-західного наріччя української мови. Напр., основне значення дієслів виво́дити/ви́вести у говірках формується на підставі руху об'єкта, який, переступаючи межу, покидає попереднє місце перебування (самостійно або із чиєюсь допомогою), при цьому важливим є насамперед не суб'єкт, а об'єкт дії, а також напрямок руху (напр., вивести в поле, вивести в люде, вивести на добру дорогу, не виводи вовка з ліса). Дослідниця зазначила, що вивчення кожного із багатозначних дієслів сприятиме кращому розумінню принципів творення багатозначності, а згодом і творення моделей багатозначності. Важливим із цього погляду є студії, які грунтуються на матеріалі українських говорів, і на матеріалі пам'яток української мови. Такий підхід зможе дати бачення історичного розвитку явища (Хобзей 2011а).

Зауважимо, що діалектологи принагідно вивчали діалектну дієслівну фразеологію різних ареалів: поліських говірок (Г.М. Доброльожа), говірок Західного Поділля (Н.Д. Коваленко), лемківського говору (Г.Ф. Ступінська), гуцульського говору (М.Я. Олійник), говірок Центральної Слобожанщини (О.Л. Плетнєва) та ін., а також досліджували обрядову фразеологію: весільну лексику українських східнослобожанських говірок (І.В. Магрицька), лексику поховального і поминального обрядів Полісся (В.І. Конобродська), лексику родинних обрядів - гуцульського говору (М.В. Бігусяк), подільсько-буковинсько-наддністрянського суміжжя (О.А. Жва- 
ва), буковинського говору (Ю.М. Руснак) та ін. Напр., Н.Д. Коваленко виділила 10 фразеосемантичних полів у говірках Західного Поділля ('Положення тіла в просторі', 'Розумова діяльність людини', 'Мовленнєва діяльність людини', 'Трудова діяльність людини' та ін.) та 46 фразеосемантичних груп (ФСГ) ('Народитися', ‘Вмерти’, ‘Спати', 'Рухатися', ‘Говорити', 'Сміятися’ та ін.) та здійснила зіставно-типологічний аналіз фразем у суміжних і дистантних зонах. За іiі спостереженнями, найчисленнішими є ФСГ 'Вмерти', 'Спати', 'Втратити або набрати вагу', 'Не мати розуму', 'Відчувати страх', 'Говорити', 'Випивати', найменшими кількісно - 'Народитися', 'Інтимні почуття людини', 'Процеси пам'яті', ‘Чванитися', 'Прикидатися', 'Мовчати'. В результаті ареального аналізу описано 147 структурно-семантичних та 17 семантичних моделей фразем (Коваленко 2011). Дієслівні фразеологізми лемківського говору поряд із субстантивними, ад'єктивними та іншими фразеологізмами розглянула Г.Ф. Ступінська і дослідила тематичні групи, що характеризують: процес переміщення, процес роботи, акт мовлення, сферу людських взаємин, сферу матеріальних інтересів та способу життя людини, морально-етичні взаємини та поведінку, стан людського організму, зорову діяльність людини, психічний стан людини, іiі життєвий цикл (Ступінська 2000). Фразеологічні одиниці гуцульського говору за семантичним і за граматичним принципами покласифікувала М.Я. Олійник (2002). У межах тематичного поля 'Людина' виділено семантичні поля: ‘Фізіологічний стан' ('Перебіг життя'), 'Внутрішній світ' ('Емоційний стан', 'Розумові здібності', 'Риси характеру'), ‘Дії і стани людини' ('Рухатися', 'Працювати', 'Уживати алкоголь', 'Говорити’), ‘Людські взаємини’ ('Дії в конфліктних ситуаціях’, 'Сімейний стан’) та ін. Зауважено, що фразеологізми, які кваліфікують зовнішній вигляд людини, іiї дії, внутрішній світ, фізіологічні особливості (тематичне поле 'Людина'), значно переважають над тими, що характеризують часо-просторові величини, явища природи тощо (тематичне поле 'Сприйняття навколишнього світу'). Також спостережено зосередження фразеологізмів навколо понять із негативною оцінкою, що підтверджує велика кількість семантичних рядів із негативною денотативною модальністю: ‘ледарювати', ‘померти', 'сваритися', 'гніватися', 'набити', 'зраджувати у шлюбі', 'обдурювати' тощо.

Сполучуваність

Питання семантики, структури, варіювання та особливостей функціонування об'єктних, локативних і темпоральних дієслівних словосполучень у новостворених східностепових говірках з'ясувала Л.С. Білик (2003а). Дослідниця запропонувала проєкт Словника дієслівних словосполучень говірок Донеччини, до якого мають увійти найуживаніші дієслова із залежними від них компонентами, та подала приклади словникових статей багатозначних дієслів вез'ти, с'тавити, 'чути та c'namu (Білик 2003б). Культурне тло діалектного дискурсу, актуалізоване в спогадах діалектоносіїв, на матеріалі східнослобожанських говірок з огляду на валентні зв’язки дієслів на позначення будівництва житлових і нежитлових споруд з іменниками вивчала К.Д. Глуховцева (2016).

Дієслово в словнику

Проблемам лексикографічного опрацювання діалектної дієслівної лексики присвячено розвідку О.В. Юсікової (2017) та охарактеризовано формування 
словникової статті реєстрового дієслова бити (на основі діалектного матеріалу с. Богдан Рахівського району Закарпатської області).

Отже, розглянуті дескриптивні праці свідчать, що сьогодні пожвавилося дослідження діалектної дієслівної лексики і семантики, зокрема науковці аналізували зв'язок з літературною мовою, з іншими діалектами, етимологію, конотацію, у складі системно-структурних утворень (лексико-семантичних полів, тематичних й лексико-семантичних груп, фразеосемантичних груп), семантичну структуру дієслів, дієслівну фразеологію, сполучуваність, дієслово в словнику. Попри системне дослідження дієслів східнополіських говірок, загалом дієслівну лексику в українських говірках вивчено недостатньо, тому існує потреба в подальших комплексних, системних наукових дослідженнях, також постають проблеми (Про проблеми сучасної української діалектології див. Кобиринка, Рябець 2018):

1) системне дослідження різних ЛСГ дієслів у різних українських діалектних ареалах, використовуючи питальник й діалектні тексти, оскільки це «простір природної реалізації говіркових явищ, засіб фіксації і збереження важливої для дослідників інформації про реальні процеси, що пронизують діалектне мовлення й говірки» (Гриценко 2000, 15),

2) з'ясування семантичної структури й чинників семантичного варіювання діалектних дієслів,

3) вивчення генези української діалектної дієслівної лексики,

4) здійснення зіставного аналізу дієслівної лексики українських говірок на тлі контактних і дистантних діалектних зон.

\section{Література}

Бичко 3.M. [Bychko Z.M.] (2000), Діалектна лексика наддністрянського говору, [Dialektna leksyka naddnistrianskoho hovoru], Тернопіль.

Бичко 3. [Bychko Z.] (2001), Структура дієслівної лексики наддністрянського говору [Struktura diieslivnoi leksyky naddnistrianskoho hovoru], «Волинь-Житомирщина: Історико-філологічний збірник з регіональних проблем», № 6, с. 233-238.

Бігусяк М. [Bigusiak M.] (2015), Динамічні прочеси в аграрному дискурсі говірок Прикарnaтmя [Dynamichni protsesy v ahrarnomu dyskursi hovirok Prykarpattia], «Волинь-Житомирщина: Історико-філологічний збірник з регіональних проблем», № 26, с. 18-28.

Білик Л.С. [Bilyk L.S.] (2003a), Дієслівні словосполучення у східностепових говірках Донеччини: автореф. дис. ... канд. філол. Наук [Diieslivni slovospoluchennia u skhidnostepovykh hovirkakh Donechchyny: avtoref. dys. ... kand. filol. nauk]: 10.02.01, Дніпропетровськ.

Білик Л.C. [Bilyk L.S.] (2003б), Спроба створення Словника дієслівних словосполучень говірок Донеччини [Sproba stvorennia Slovnyka diieslivnykh slovospoluchen hovirok Donechchyny], «Діалектологічні студії. 1. Мова в часі і просторі. Збірник на пошану Дмитра Гринчишина», с. 291-299.

Вихованець I., Городенська К. [Vykhovanets I., Horodenska K.] (2004), Теоретична морфологія украӥнської мови: академічна граматика украӥнської мови [Teoretychna morfolohiia ukrainskoi movy: akademichna hramatyka ukrainskoi movy], Київ. 
Возний T.M. [Voznyi T.M.] (1978), Взаємодія украӥнської літературної мови та діалектів y галузі дієслівної лексики (на матеріалі бойківських дієслів на -отати [-етати]) [Vzaiemodiia ukrainskoi literaturnoi movy ta dialektiv $u$ haluzi diieslivnoi leksyky (na materiali boikivskykh diiesliv na -otaty [-etaty])], «Проблеми дослідження діалектної лексики і фразеології української мови», с. 141-142.

Глуховцева К.Д. [Hluhovtseva K.D.] (2008), Етнолінгвістичні основи семантичної експресії дієслів (на матеріалі украӥнських східнослобожанських говірок) [Etnolinhvistychni osnovy semantychnoi ekspresii diiesliv (na materiali ukrainskykh skhidnoslobozhanskykh hovirok)], «Лінгвістика», № 1 (13), с. 171-180.

Глуховцева К.Д. [Hluhovtseva K.D.] (2016), Назви конкретних фізичних дій у діалектному дискурсі українських східнослобожанських говірок [Nazvy konkretnykh fizychnykh dii u dialektnomu dyskursi ukrainskykh skhidnoslobozhanskykh hovirok], «Лінгвістика», № 2 (35), c. $76-84$.

Гриценко П.Ю. [Hrytsenko P.Yu.] (2000), Текст як простір вияву діалектних явищ [Tekst yak prostir vyiavu dialektnykh yavyshch], «Збірник лінгвістичних праць: до 60-річчя проф. О.А. Колесникова», с. 9-15.

Дзендзелівський Й.О. [Dzendzelivskyi J.O.] (1960), Сільськогосподарська лексика говорів Закарпаття (лексика, пов'язана з обробітком землі, вирощуванням сільськогосподарських культур та збором урожаю) [Silskohospodarska leksyka hovoriv Zakarpattia (leksyka, poviazana z obrobitkom zemli, vyroshuvanniam silskohospodarskykh kultur ta zborom urozhaiu)], «Studia Slavica Hungarisa», т. 10, c. 33-97.

Дзендзелівський Й.O. [Dzendzelivskyi J.O.] (1987), Програма для збирання матеріалів до Лексичного атласу украӥнської мови [Prohrama dlia zbyrannia materialiv do Leksychnoho atlasu ukrainskoi movy], Київ.

Івченко А. [Ivchenko А.] (1999), Фразеологізми зі значенням 'бити, карати' в українських народних говорах: ономасіологічний аспект [Frazeolohizmy zi znachenniam 'byty, karaty' $v$ ukrainskykh narodnykh hovorah: onomasiolohichnyi aspekt], «Збірник Харківського історико-філологічного товариства. Нова серія», т. 8., с. 159-172.

Карп’юк М.Д. [Karpiuk M.D.] (1978), Діалектні дієслівні варіанти як результат мовної інтерференціï [Dialektni diieslivni varianty yak rezultat movnoi interferentsii], «Проблеми дослідження діалектної лексики і фразеології української мови», с. 178-179.

Коваленко Н.Д. [Kovalenko N.D.] (2011), Фраземіка говірок Західного Поділля [Frazemika hovirok Zahidnoho Podillia], Кам'янець-Подільський.

Кобиринка Г.С., Рябець Л.В. [Kobyrynka H.S., Riabets L.V.] (2018), Українська діалектологія: витоки та перспективи [Ukrainska dialektolohiia: vytoky ta perspektyvy], «Українська мова», № 4, с. 92-100.

Ковач Г. [Kovach Н.] (2011), Дієслівні характеристики вискаленого дикого звіра в українських говірках Закарпаття [Diieslivni kharakterystyky vyskalenoho dykoho zvira v ukrainskykh hovirkakh Zakarpattia], «Науковий вісник Ужгородського університету. Серія: Філологія. Соціальні комунікації», вип. 25, с. 60-63.

Лавер B.I. [Laver V.I.] (1977), Фразеологізми в південно-західних українських говорах ареалу Kарпат із значенням акту мовлення [Frazeolohizmy v pivdenno-zakhidnykh ukrainskykh hovorakh arealu Karpat iz znachenniam aktu movlennia], «XIV Республіканська діалектологічна нарада: тези доп.», с. 133-135.

Лєснова В.B. [Liesnova V.V.] (2011), Семантика діалектних дієслів негативної оцінки [Semantyka dialektnykh diiesliv nehatyvnoi otsinky], «Лінгвістика», № 1 (22), с. 62-70. 
Міроненко T.B. [Mironenko T.V.] (2014), Семантика дієслів фізичної дї в аграрному дискурсі украӥнських говірок Воронежчини [Semantyka diiesliv fizychnoi dii v ahrarnomи dyskursi ukrainskykh hovirok Voronezhchyny], «Діалекти в синхронії та діахронії: загальнослов'янський контекст», с. 339-343.

Ніколаснко I.O. [Nikolaienko I.O.] (2005), Лексика традиційного ткацтва в украӥнських східнослобожанських говірках [Leksyka tradyciinoho tkatstva $v$ ukrainskykh skhidnoslobozhanskykh hovirkakh], Луганськ.

Олійник М.Я. [Oliinyk М.Үа.] (2002), Фразеологія гуцульських говірок: автореф. дис. ... канд. філол. наук [Frazeolohiia hutsulskykh hovirok: avtoref. dys. ... kand. filol. nauk]: 10.02.01, Львів.

Познанський P.B. [Poznanskyi R.V.] (2012), Дієслова лексико-семантичного поля «Аграрне виробництво (рослинництво)» в гуиульських говірках [Diieslova leksyko-semantychnoho polia «Ahrarne vyrobnytstvo (roslynnytstvo)»v hutsulskykh hovirkakh], «Вісник Прикарпатського університету. Філологія», вип. 32-33, с. 335-340.

Познанський P.B. [Poznanskyi R.V.] (2013a), Дісслова лексико-семантичного поля «аграрне виробництво (рослинництво)» в говорах Карпатського регіону [Diieslova leksykosemantychnoho polia "ahrarne vyrobnytstvo (roslynnytstvo)» v hovorakh Karpatskoho rehionu], «Матеріали II Міжнародної спільної українсько-американської науково-практичної конференції «Карпати-Аппалачі: Формування особистості в контексті сталого розвитку гірських регіонів». 24-26 вересня 2013 р.», с. 165-168.

Познанський P.B. [Poznanskyi R.V.] (2013б), Дієслова лексико-семантичного поля «аграрне виробництво (рослинництво)» в українській мові: критерії ідентифікації та типологія [Diieslova leksyko-semantychnoho polia "ahrarne vyrobnytstvo (roslynnytstvo)» v ukrainskii movi: kryterii identyfikacii ta typolohiia], «Філологічні студіï: Науковий вісник Криворізького національного університету», вип. 9, с. 334-343.

Прокопенко B.A. [Prokopenko V.A.] (1961), Про дієслівну лексику буковинських говірок [Рго diieslivnu leksyku bukovynskykh hovirok], «Праці Х Республіканської діалектологічної наради», с. 95-104.

Романина I.P. [Romanyna I.R.] (2015), Структурно-семантичні особливості діалектних текстів про чуда в наддністрянському говорі: дис. ... канд. філол. наук [Strukturnosemantychni osoblyvosti dialektnykh tekstiv pro chuda v naddnistrianskomu hovori: dys. ... kand. filol. nauk], Львів.

Сердега P.Л. [Serdeha R.L.] (2012), Сільськогосподарська лексика в говірках Центральної Слобожаншини (Харківщини) [Silskohospodarska leksyka v hovirkakh Tsentralnoi Slobozhanshyny (Kharkivshchyny)], Харків.

Ступінська Г.Ф. [Stupinska H.F.] (2000), Фразеологія лемківського говору украӥнської мови: автореф. дис. ... канд. філол. наук [Frazeolohiia lemkivskoho hovoru ukrayinskoi movy: avtoref. dys. ... kand. filol. nauk]: 10.02.01, Івано-Франківськ.

Тищенко Т. [Tyshchenko T.] (2009), Семантика номінації обрядодій східноподільського родильного обряду [Semantyka nominatsii obriadodii skhidnopodilskoho rodylnoho obriadu], «Вісник Прикарпатського національного університету. Філологія (Мовознавство)», вип. $21-22$, c. $48-52$.

Толстой Н.И. [Tolstoi N.I.] (1997), Избранные труды [Izbrannyie trudy], т. I, Славянская лексикология и семасиология [Slavianskaia leksikolohiia i semasiolohiia], Москва.

Хобзей Н.B. [Khobzei N.V.] (2010a), Дієслова вилітати/вилетіти у складі ідіом та паремій (на матеріалі говірок південно-західного наріччя української мови) [Diieslova vylitaty/ 
vyletity $u$ skladi idiom ta paremii (na materiali hovirok pivdenno-zakhidnoho narichchia ukrainskoi movy)], «Лінгвістика», № 3 (21), ч. 1, с. 206-209.

Хобзей Н.В. [Khobzei N.V.] (2010б), Дієслова з префіксом ви- в говірках північного та південно-західного наріч української мови: до пошуку паралелей [Diieslova z prefiksom vy$v$ hovirkakh pivnichnoho ta pivdenno-zahidnoho narich ukrainskoi movy: do poshuku paralelei], «Волинь - Житомирщина. Історико-філологічний збірник з регіональних проблем», вип. 22 (ii), с. 283-288.

Хобзей Н.В. [Khobzei N.V.] (2010в), Дієслова руху з префіксом ви-, або звідки та куди виходять, виїжджають і таке інше, в колядках та щедрівках [Diieslova rukhu z prefiksom vy-, abo zvidky ta kudy vyhodiat, vyizhdzhaiut i take inshe, v koliadkakh ta shchedrivkakh], «Народна творчість українців у просторі і часі. Матеріали міжнародної наукової конференції в рамках VI Міжнародного фестивалю українського фольклору „Берегиня”», c. $381-390$.

Хобзей Н.В. [Khobzei N.V.] (2011a), Багатозначні дієслова в говорах південно-західного наріччя: виводити/вивести Bahatoznachni diieslova $v$ hovorakh pivdenno-zakhidnoho narichchia: vyvodyty/vyvesty], «Мовознавчий вісник», с. 100-105.

Хобзей Н.B. [Khobzei N.V.] (2011б), Багатозначні дієслова в говорах південно-західного наріччя: вискакувати/вискочити [Bahatoznachni diieslova v hovorakh pivdenno-zakhidnoho narichchia: vyskakuvaty/vyskochyty], «Лінгвістика», № 1 (22), с. 85-90.

Хобзей H.B. [Khobzei N.V.] (2011в), Дієслова руху «знизу - вгору» в говірках південно-західного наріччя [Diieslova rukhu «znyzu - vhoru» $v$ hovirkakh pivdenno-zakhidnoho narichchia], «Лінгвістика», № 3 (24), ч. 1, с. 120-125.

Хобзей Н.В. [Khobzei N.V.] (2012), Дієслова руху з префіксом ви- в говірках південно-західного наріччя української мови: виходити/вийти [Diieslova rukhu z prefiksom vy- $v$ hovirkakh pivdenno-zakhidnoho narichchia ukrainskoi movy: vyhodyty/vyity], «Gwary Dziś», т. 6: Aktualne problemy dialektologii stowiańskiej, c. 97-104.

Холодьон О.M. [Kholodon O.M.] (2016), Дієслова мовлення у східнополіських говірках (східнослов'янський контекст) [Diieslova movlennia u skhidnopoliskykh hovirkakh (skhidnoslovianskyi kontekst)], «Компаративні дослідження слов'янських мов і літератур: пам'яті академіка Леоніда Булаховського», № 29, с. 134-143.

Холодьон O.M. [Kholodon O.M.] (2017), Семантична варіативність дієслівної лексики в східнополіському діалекті: дис. ... канд. філол. наук [Semantychna variatyvnist diieslivnoi leksyky v skhidnopoliskomu dialekti: dys. ... kand. filol. nauk]: 10.02.01, Київ.

Холодьон О. [Kholodon O.] (2018), Евфемізми як чинник лексичної варіативності у східнополіських говірках (на матеріалі дієслівної лексики) [Evfemizmy yak chynnyk leksychnoi variatyvnosti u skhidnopoliskykh hovirkakh (na materiali diieslivnoi leksyky)], «Діалектологічні студії. 11: Слово - словник - корпус», с. 186-197.

Холодьон О. [Kholodon O.] (2019), Невербальні засоби вираження семантики дієслів Східного Полісся: види і функиї жестів [Neverbalni zasoby vyrazhennia semantyky diiesliv Skhidnoho Polissia: vydy i funktsii zhestiv], «Лінгвістика», с. 53-64.

Чабаненко B.A. [Chabanenko V.A.] (1977), Емоиійно-експресивна лексика в украйнських степових говірках Запорізької області [Emotsiino-ekspresyvna leksyka v ukrainskykh stepovykh hovirkakh Zaporizkoi oblasti], «XIV Республіканська діалектологічна нарада», c. 101-102.

Юсип-Якимович Ю. [Yusyp-Yakymovych Yu.] (2007), Ономатопоетика украӥнських говорів Kарпат: семантична, фонетична, словотвірна структура та похідність ономатопів 
[Onomatopoetyka ukrainskykh hovoriv Karpat: semantychna, fonetychna, slovotvirna struktura ta pokhidnist onomatopiv], Ужгород.

Юсікова О.В. [Yusikova O.V.] (2010), Особливості дієслів із семантикою руху в просторі (на матеріалі говірок Закарпаття) [Osoblivosti diiesliv iz semantykoiu rukhu v prostori (na materiali hovirok Zakarpattia)], «Лінгвістика», № 3 (21), ч. 1, с. 150-157.

Юсікова O.В. [Yusikova O.V.] (2013), Із спостережень над семантикою дієслова класти в говіриі села Богдан Рахівського району Закарпатської обл. Iz sposterezhen nad semantykoiu diieslova klasty $v$ hovirtsi sela Bohdan Rakhivskoho raionu Zakarpatskoi obl.], «Мовознавчий вісник», вип. 16-17, с. 56-62.

Юсікова O. [Yusikova O.] (2017), Дієслово бити у говірках Закарпаття: лексикографічний acnекm [Diieslovo byty u hovirkakh Zakarpattia: leksykohrafichnyi aspekt], «Науковий вісник Ізмаїльського державного гуманітарного університету. Серія: Філологічні науки», вип. 38 , с. $73-78$. 